\title{
Problem-Based Learning in a Medical School: Implementations Challenges
}

\section{Aprendizagem Baseada em Problemas em um Curso de Medicina: Desafios na sua Implementação}

\author{
Kátia Terezinha Alves Rezende ${ }^{I}$ [C \\ Maria Cristina Guimarães da Costa ${ }^{I}(\mathbb{D}$ \\ Matheus Eduardo Rodrigues ${ }^{I}$ (iD \\ Silvia Franco da Rocha Tonhom ${ }^{I}$ (iD
}

\section{KEYWORDS}

- Problem-Based Learning.

- Medical Education.

- Teaching.

Introduction: Considering an integrated curriculum that is guided by dialogical competence according to the National Curriculum Guidelines, the Systematized Educational Unit (UES) and the Professional Practice Unit (UPP) constitutes the curriculum of a medical course in a municipality in the countryside of the state of São Paulo, Brazil. Problem-Based Learning (PBL) is used in the UES and the problematization is used in the Professional Practice Unit as teaching methodologies, seeking an organization that leads to a training that is coherent with the public health sector and the national education scenario. The UES is the focus of this study because we observed that there are divergences among teachers regarding their role as tutors. Thus, we observed that the teaching methodology currently employed at Famema led us to some questions: Do the teachers consider themselves qualified to work with the PBL method? How do evaluations contribute to the teaching-learning process? Thus, this study aimed to analyze the teachers' understanding of their ability to work with the PBL and the relevance of evaluations for the teaching-learning process in the UES. Method: This is an exploratorydescriptive study with a qualitative approach. Data collection was carried out using a semi-structured interview with teachers who work with the $1^{\text {st }}$ to $4^{\text {th }}$ years in the UES of the medical course, and the selection of the participants was carried out from a non-probabilistic sample of intention, totaling 16 teachers, including four teachers of each of the first four years of the course. The analysis of the data was performed by Content Analysis in the thematic modality, which allowed the definition of two thematic axes: Challenges for teacher training and Potentials and limits of the implemented evaluation process. Results: The trajectory of the PBL in the teachinglearning process from the point of view of teachers showed us a variety of understandings. As for teacher training, weaknesses were identified in the development of the tutoring process, and that the strategies used for training need to be reviewed regarding their implementation and the inclusion of the professionals into the process. Regarding the evaluation, it was observed that the teachers demonstrate difficulties in carrying out an evaluation of the students while integrating the affective, cognitive and psychomotor dimensions. Conclusion: Therefore, regardless the time of the curriculum implementation, Permanent Education should constitute a powerful space for teacher training and process management. 


\section{PALAVRAS-CHAVE}

- Aprendizagem Baseada em Problemas.

- Educação Médica.

- Ensino.

\section{RESUMO}

Introdução: Considerando um currículo integrado e orientado por competência dialógica de acordo com o exposto nas Diretrizes Curriculares Nacionais, a Unidade Educacional Sistematizada (UES) e a Unidade de Prática Profissional (UPP) compõem o currículo de um curso de Medicina de um município do interior paulista. Utilizam-se a Aprendizagem Baseada em Problemas (ABP) na UES e a problematização na UPP como metodologias de ensino, com o objetivo de buscar uma organização que conduza a uma formação coerente com o setor de saúde pública e o cenário de educação nacional. A UES é o foco deste estudo, pois notamos que há divergências entre os docentes sobre o papel do tutor. Com base nisso, a metodologia de ensino vigente na Faculdade de Medicina de Marília (Famema) nos levou aos seguintes questionamentos: "O professor se considera capacitado para atuar no método ABP?" e "De que forma as avaliações contribuem com o processo de ensino-aprendizagem?”. Assim, este trabalho teve por objetivo analisar a compreensão do docente acerca de sua capacitação para atuar na ABP e da pertinência das avaliações no processo ensino-aprendizagem na UES. Método: Trata-se de estudo do tipo exploratório-descritivo com abordagem de natureza qualitativa. A coleta de dados se deu pela realização de entrevista semiestruturada com professores que desenvolvem atividades na UES do primeiro ao quarto ano do curso de Medicina, selecionaram-se os participantes a partir de uma amostra não probabilística de intenção, totalizando 16 professores, sendo quatro de cada um dos quatro primeiros anos do curso.No exame dos dados, adotou-se a análise de conteúdo na modalidade temática que permitiu a definição de dois eixos temáticos: desafios para a formação docente e potencialidades e limites do processo de avaliação instituído. Resultados: A trajetória da ABP no processo de ensino-aprendizagem sob a ótica dos docentes nos mostrou uma variedade de compreensões. Em relação à formação docente, identificaram-se fragilidades no desenvolvimento do processo tutorial. Além disso, constatou-se que as estratégias utilizadas para a capacitação precisam ser revistas quanto à implementação e à inserção dos profissionais nelas. Observou-se que os docentes demonstram dificuldades em realizar uma avaliação dos estudantes integrando as dimensões afetivas, cognitivas e psicomotoras. Conclusão: Assim, independentemente do tempo de implementação do currículo, a educação permanente deve se constituir como espaço potente para a capacitação docente e a gestão do processo.

Received on 8/13/19

Accepted on $7 / 23 / 20$

\section{INTRODUCTION}

Based on the Brazilian Law of National Education Guidelines and Bases (LDB) $9.394^{1}$ and later on the National Curricular Guidelines for the medical course - $\mathrm{DCN}^{2}$, the School of Medicine of Marília (Famema, Faculdade de Medicina de Marília) underwent a process for the restructuring of its academic curriculum, which led it to follow a trend discussed worldwide: to associate teaching with the community, an issue also acclaimed by the creation, in 1988, of the Brazilian Unified Health System (SUS, Sistema Único de Saúde). This change and restructuring process culminated in 2003 with the participation in the Incentive Program for Curricular Changes in Medical Courses - PROMED 3 . This is structured in three axes, namely: theoretical advice, pedagogical approach and practice scenarios ${ }^{4}$. Thus, the teaching-learning in the Famema medical course comprised the triad - student-centered, problembased and community-oriented learning - essential for the structuring of the multidisciplinary educational units that comprise the medical undergraduate curriculum. Subsequently, the integrated curriculum was established, guided by dialogical competence, which is structured into a Systematized Educational Unit (UES, Unidade Educacional Sistematizada) and articulated with the Professional Practice Unit (UPP, Unidade de Prática Profissional).

Therefore, in the new curricular model of Famema, the pedagogical approach developed at UES was based on Problem-Based Learning (PBL). PBL first appeared in 1969, in Canada, at McMaster University and has since spread throughout the world as a pedagogical model in adult education. It is a student-centered teaching-learning process, that is, the students are the managers of their learning ${ }^{5}$.

In this method, students are organized into small groups under the guidance of a tutor, who needs to master the tutorial steps, the principles that govern the active teaching-learning method and the technique that guides the group work. The tutorial process must follow nine steps ${ }^{6,7}$, which encompass: the presentation of the problem (reading by the group); clarification of some unknown terms and doubts about the problem; definition and summary of the problem, with identification of relevant points; problem analysis using previous knowledge, called "brainstorming"; developing hypotheses to explain the problem and identify knowledge gaps; definition of learning goals, where the students create questions to be researched and answered; active search for information and individual study; sharing the obtained information and applying it to understand the proposed problem and, finally, evaluating the work of the group and its members.

In the UES, the students' performance is assessed using an evaluation tool that contributes to the teaching-learning process, which is completed by the teacher who assessed them. As part of the evaluations, we also have the Cognitive Evaluation Exercise (CEA), which is a written response instrument that contemplates the studied contents, and has a multidisciplinary character, addressing biological, psychological and social aspects and maintaining basic-clinical integration ${ }^{8}$.

REVISTA BRASILEIRA DE EDUCAÇÃO MÉDICA

2 44 (4) : e119; 2020 
Considering the curriculum of the Famema medical course and based on empirically identified perceptions, divergences can be observed among the teachers regarding their role as tutors. Some teachers do not develop the teaching-learning process according to what is recommended, that is, tutorial steps fail to be followed, and among them one can highlight the development of hypotheses that go beyond the evaluation of the group and student performance.

Considering this, some questions arise:

- How do teachers consider themselves to be qualified to work with the PBL method?

- How do assessments contribute to the teaching-learning process?

Thus, this study aims were: to analyze the teachers' understanding of their training to work with PBL and the development of assessments in the teaching-learning process in UES.

\section{METHOD}

It is an exploratory-descriptive field research, based on a qualitative approach. This choice was due to the fact that it safeguards the mastery in describing a certain phenomenon to expand knowledge, as well as to characterize it ${ }^{9}$. The field study is important as the researcher needs to go to the place where the phenomenon occurs and seeks to gather a set of data to be collected and documented. The qualitative analysis, in turn, can explore significances and meanings such as values, beliefs, habits, attitudes and provided opinions ${ }^{10}$.

The study was carried out at Famema, located in a municipality in the countryside of the Midwest region of the state of São Paulo, Brazil. It is a public higher education institution, founded in 1966, which offers courses in Medicine and Nursing, with 80 and 40 students admitted per year, respectively. The medical course is a full-time, face-to-face teaching modality and has a minimum time of completion of six years. The academic level is an undergraduate school and the academic degree is equivalent to a bachelor's degree ${ }^{11}$.

The study population consisted of teachers who carry out their activities at UES from the $1^{\text {st }}$ to the $4^{\text {th }}$ year of the medical course, totaling 65 tutors. Of these, 14 (21.5\%) teachers work in the first year, 16 (24.6\%) in the second, $17(26.2 \%)$ in the third and $18(27.7 \%)$ in the fourth year. In the first three years, the teachers are from different professional backgrounds (physicians, nurses, biologists, pharmacists, among others) and the fourth year teachers consist exclusively of medical tutors. Participant selection was carried out in a non-probabilistic sample of intention, with four teachers from each of the first four years of the medical course, totaling 16 tutors. They were also chosen based on the variables: gender, how long they have worked with PBL and professional training, thus guaranteeing a sample that made it possible to cover multiple dimensions and investigate the problem in its entirety.

Data collection was performed through a semi-structured interview that was recorded and transcribed by one of the researchers. Through this data collection method, the details of the acquired information are increased and strengthened in the subjectivity of the teachers' answers ${ }^{12}$.

The study was approved by the Research Ethics Committee Involving Human Subjects of the Medical School of Marília n. 1,273,569, CAAE: 49104915.0.0000.5413. The teachers who agreed to participate in the research signed the Free and Informed Consent Form (FICF) before data collection.
The analysis was carried out based on Content Analysis in the Thematic Mode, which aims at discovering the core of communication meanings that represent something for the goals to be attained ${ }^{10,13}$. Initially, the material was thoroughly read, allowing oneself to be imbued by the content. Thus, it was possible to have a view of the entire set, to apprehend the particularities, to create assumptions, to choose the format of the initial classification and finally to define the theoretical concepts that guided the analysis.

Then, the material was explored, and the excerpts of the interviews were distributed according to a classification that included teacher training and the development of tutoring assessment.

From then on, a reading of the content of each class was carried out, establishing a dialogue between the parts of the analysis text. Next, the core of meanings was identified by means of inference that, after being reorganized, constituted two thematic axes: Challenges for teacher training and Potentialities and limits of the implemented evaluation process, as shown in Frame 1.

\section{RESULTS AND DISCUSSION}

\section{Characterization of the participants}

The research participants included three (18.75\%) biologists, one (6.25\%) biomedical scientist, three (18.75\%) pharmacists, one $(6.25 \%)$ nurse and eight $(50 \%)$ physicians, totaling a population with eight $(50 \%)$ male and eight (50\%) female participants.

Regarding age, two (12.50\%) of the teachers were older than 60 years; six (37.50\%) were aged between 50 and 59 years; five (31.25\%) between 40 and 49 years old and three (18.75\%) between 30 and 39 years. As for the time working at the institution, two (12.50\%) tutors had been working

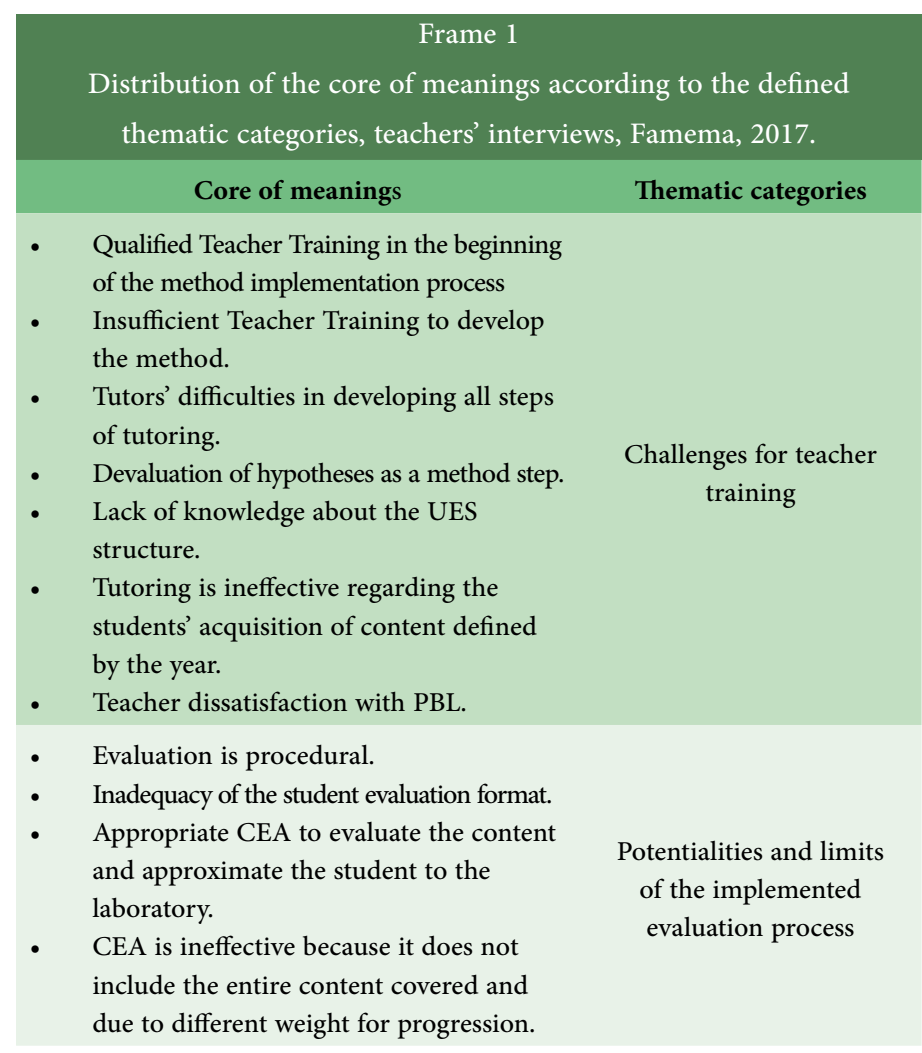

Source: prepared by the authors

REVISTA BRASILEIRA DE EDUCAÇ̃̃o MÉDICA

3 44(4) : e119; 2020 
between less than one year and five years; two (12.50\%) between six and ten years; two (12.50\%) between 11 and 15 years; two (12.50\%) between 16 and 20 years, and eight (50\%) had been working for more than 20 years. Of the interviewees, eight (50\%) teachers participated in training carried out at the beginning of the PBL implementation process at Famema and eight (50\%) started using the method after the initial training cycle.

\section{Topics}

\section{Challenges for teacher training}

In this study, part of the interviewees was submitted to Continuing Education (CE), which was carried out by specialists that worked outside the institution, between 1996 and 1997, when the curricular change process started.

At the time, there were many continuing education courses and we took these CE courses on assessment, group dynamics, and people also came from outside the institution who, not necessarily had experience with $P B L$, but with these topics, evaluation, group dynamics, etc. In the beginning it was a very massive investment and then the institution gained autonomy (I4).

Most of the teachers who participated in this initial training process considered it to be extremely beneficial, as they were presented with the necessary basis for the performance and adequacy to the new pedagogical proposal. "I think what happened at the beginning was very dynamic, it was very practical; we were experiencing that practice and it was constant. I think it contributed a lot for me to understand this process" (I7).

The implementation of pedagogical innovations is accompanied by a feeling of uncertainty, due to the fear of the unknown, mainly by those who feel they do not belong to the model implementation. Therefore, several authors affirm that it is essential to implement a teacher development program to improve their performance at the university, avoiding their frustration and the abandonment of the academic activity ${ }^{14}$.

Teacher training at Famema went through a period characterized by robust institutional investment in teacher training, which is the moment of implementing the PBL method. With this process of pedagogical change, it was necessary to work intensively with the teachers who would work with this new approach and thus, training programs for tutors were developed before the development of activities started ${ }^{11}$.

$\mathrm{CE}$ was also developed during the process, which addressed topics such as bioethics, principles of adult education, evidence-based medicine, and group dynamics, among others ${ }^{15}$.

Over the years, these teachers were responsible for the training of new tutors, who qualified by following the process, assuming the role of co-tutor at that moment and, later, assuming their role as a tutor. However, this format of training alone was not considered sufficient by the interviewees:

In fact, there was no training. And I was a co-tutor and just like the other tutor did, it is the way I do it today. [...] the school itself had one or another training, not necessarily for tutoring specifically, of the tutorial process (I1).

Traditionally, when analyzing university faculties, the strong technical-scientific training is evident, in contrast with the deficiencies in didactic-pedagogical training. Thus, there is a need for strategies to overcome this gap, such as the implementation of Permanent Education (PE). Training for teaching practice can also happen in many different ways, emphasizing, in addition to the training promoted by universities or their postgraduate courses, the exchange with students, exchange between peers and in scientific production or study groups ${ }^{16}$.

The PE is a pedagogical approach developed in the health sector that allows interactions between teaching and healthcare ${ }^{17}$. Therefore, work allows the redirection of the professionals' practices, overcoming the gaps in the training field ${ }^{18}$.

Since 2002, Famema started to carry out PE as a central element in its Teacher Development Program (TDP), which aims, based on the reflection that focuses on the teachers' daily lives, to promote the growth of the group and its components with the construction of learning and transformations into practice. Activities are often carried out in groups with a maximum of 12 teachers, with weekly meetings lasting 60 minutes. The work is coordinated by two teachers in each group, with the objective of working on the pedagogical and group process ${ }^{11}$.

Currently, most respondents refer little adherence to the CE process and do not consider that the activities developed in the PE are sufficient to give theoretical density to the teaching-learning process.

Currently I do not do any more [CE], I got tired, literally. Because the training has not changed, and we have so many things to do; so, I do not do it anymore. (I10)

At PE, we discuss the problem with students a lot, one or another difficulty, but the theoretical part that could be worked on at PE ends up not being done, because it is also a space to discuss these other types of problems. (I1)

Treviso and $\operatorname{Costa}^{16}$ found some factors that influence the low teacher adherence to the training activities proposed by educational institutions, and among them, the scarcity of time, the impediment to participate due to personal reasons and an unattractive approach stand out. The authors propose that creative strategies be carried out in the training at higher education institutions aiming to stimulate and promote the motivation of teachers, promoting a space for the exchange of knowledge and not driving off those who participate. Moreover, they highlight the importance of planning and disseminating it in advance, ensuring better adherence by all participants.

In this sense, there is an opportunity to review the way Famema carries out both its PE and CE actions. Even the teachers who have been working for a shorter period of time at the institution are faced, in the meetings, with schedules of repeated and /or unattractive subjects. Thus, the question remains whether the PE space is being used only to expose difficulties found in the tutoring sessions or other institutional problems, not constituting a space to subsidize the theoretical construction regarding the teaching-learning process. Also, how many of the demands that have arisen are being considered important to be solved for the fluidity of the process, as $\mathrm{PE}$ is not yet being a management tool.

A feeling of frustration can be observed among the interviewed Famema teachers. Many point out the low adherence or dissatisfaction with the PE process. In addition, teachers who joined after the implementation of the method, do not report the same enthusiasm envisioned by those 
who were present since the beginning. They also feel there is a lack of training for their performance and disqualify the one performed in the co-tutoring model only.

Such feelings end up reflecting in the teacher's action as a tutor. One aspect is found in the fact that none of the interviewed tutors mentions the nine steps of the tutorial process. Thus, only the minority of the tutors mention the development of hypotheses and evaluation in the development of the process.

[...] I try to develop it in the steps we take here, obviously I can't follow 100\%; there are a lot of things too, I won't be hypocritical to say that I agree $100 \%$ with the method. I try! Not me correcting the method, who am I to correct the method, but inside the group, if the group allows it, if it feels comfortable, we will discuss the issues and try to digest them as deeply as possible in any and all matters (I13).

I do individual readings, then collective readings, clarification of terms. 'Brainstorming' is a process that I highly respect. When I do the tutorial process, I like to explore a lot of previous knowledge so that we can move forward. Individual and collective evaluation and then, continuing the discussions, I tend to participate, to be very attentive to the discussions (I4).

The nine steps of the tutorial process are based on the scientific process and failure to follow these steps ends up compromising a meaningful learning, since the latter actually takes place from the moment the student is in a situation of cognitive conflict, a fundamental affective factor in the search, ensuring changes in its thought structure ${ }^{19}$.

The importance of following the tutorial steps is also emphasized, which guarantees the educational bases for the development of essential skills in the professional practice of future doctors, such as the construction of hypothetical-deductive reasoning and the achievement of the capacity to self-manage their knowledge $e^{20}$.

Moreover, it was verified that the teachers are unaware of the other UES activities or even mention the UPP as belonging to it. Few tutors mention consulting activities, conferences and practical activities. Here, it is still possible to observe the concept identified in many teachers that the UES consists solely or exclusively of tutoring, devaluing the other teaching-learning scenarios.

I don't even know how to describe them all. I know you have a Professional Practice Unit, but I don't know how to describe them all (I2).

I don't know all of them. I know there are lectures ... and then I don't know anymore (I15).

The teachers point out that the unit contributes to gaps in training in relation to the content given to the student.

[...] if we look at the theoretical-pedagogical assumptions, looking at our curriculum construction and the fact that our curriculum is guided by competencies, we would need to bring cognitive support into the systematized educational unit to allow the medical students to develop their medical practice based on their training. [...] But we still do not have that clarity. Perhaps because I do not have that clarity, from my viewpoint, we allow some gaps in the student's cognitive training to happen here at Famema (I12).

In PBL, the tutor does not specifically define the developed content as in the traditional teaching model. Because it is a student-centered methodology, teachers who are not adequately trained in the method feel uncomfortable because there is no transmission of knowledge. This new role is observed as one of the main barriers in adopting active methodologies in schools previously established in the traditional teaching model. Teachers' reluctance to institutionalize such innovation is observed when there is a lack of experience and theoretical foundations ${ }^{21}$.

Participation in PE spaces can allow reflection on their practices, proving to be essential for both teachers who were part of the implementation of the PBL method at Famema, as well as an opportunity for training for those who joined after this process. It also highlights the possibility of rethinking how the training of teachers and their inclusion in the PBL scenario is being carried out, a pedagogical innovation that lacks important movements for inclusion and theoretical foundation, so that they promote meaningful learning.

\section{Potentialities and limits of the established evaluation process}

Since students are the main subject of their learning in PBL, it is expected that the evaluation will be a guiding instrument of transformation in the teaching-learning process. Thus, before punishing or supervising, the evaluation, whether summative or formative, oral or written, daily or half-yearly, has the role of subsidizing self-assessment and providing students with the ability to identify their qualities and weaknesses, with enough time for their recovery ${ }^{6,8}$.

It was observed that many teachers consider the daily assessment carried out during tutoring as the best time to accompany the students and lead them to reflect on their weaknesses and potentials.

So, every day I evaluate the students, mainly so that they are not surprised with a "sufficient" or "insufficient" at the end (I5).

I think the evaluation forms are very broad and, when you read it, it does not say much, it becomes very vague. I think it is time to review the forms (I8).

As the students use this format, I think it is still very inadequate, due to lack of knowledge, due to laziness on both sides, because evaluating is difficult; you need time to sit down, think about your student, and write those formats[...] (I10).

This is the formative assessment that aims to show to the institution, the teacher and the student the results obtained during the course, being a continuous and evolutionary process that, by integrating the affective, cognitive and psychomotor dimensions, has the function of promoting the development not only of the students but also of the faculty and professionals involved in the process ${ }^{8}$.

Moreover, the approximation between the teacher and the student, both actors in this evaluation process, provides greater security and monitoring of their performance.

Despite the potentials pointed out in the assessment carried out in

$5 \mid$\begin{tabular}{l|l} 
REVISTA BRASILEIRA DE EDUCAÇÃO MÉDICA \\
\hline 44 (4) : e119; 2020
\end{tabular} 
tutoring, the evaluation format of student performance in the UES is subject to criticism by teachers.

The format should be a summary of assessments carried out by the teachers during the development of tutorials ${ }^{22}$. However, it can be verified that the teachers consider it difficult to fill out, laborious and that it does not fully reflect what is explored during the tutorial process.

The teachers mentioned the CEA as the main cognitive assessment type. This exercise was considered an adequate evaluation tool for bringing the students closer to the covered subjects and taking them to the laboratories. This instrument also favors the discussion of a problem case allowing the development of scientific reasoning: "the differential of the CEA lies in the existence of a problem situation, a larger vignette, I see the differential in it. Because if you change the teaching-learning process, the evaluation must also be changed" (I4).

Despite the potentialities pointed out in relation to the CEA, it is evident that the evaluation is understood along with its characteristic of monitoring and punishing the student: "I am particularly afraid of the CEA because you change a whole methodology into a relapse, as if it were the SAT test day again" (I6).

In this sense, it can be observed that the practice of cognitive assessment still determines or directs the content to be studied, differently from what is intended with the recent investments in new pedagogical strategies, where the assessment is expected to be the consequence of a stimulating and, in fact, significant learning ${ }^{22}$.

This practice is also criticized for not being able to cover the entire content.

We know that this [CEA] is insufficient, it is not possible to include the entire content in essay questions, otherwise we will have a test with 20, 25 questions, which I think would be very complicated for the student (I12).

I think the CEA is a good thing, you must have it to see whether they are really learning what they are studying (I15).

Teachers identify that the CEA has a different weight in the student's evolution, as they value this exercise to the detriment of the performance evaluation in the tutorial process.

[...] what makes you fail at school? The CEA. Why doesn't tutoring fail? Because in my point of view it is poorly evaluated. No adequate consideration is given to the performance evaluation format in tutoring that it should have because, in theory, in the evaluation notebook, the student's performance must be 100\% satisfactory. Both in the CEA and in the tutorial process. And which student has $100 \%$ performance in tutoring? And when we read the formats, we do not see that. Because the teacher may not have this training, does not have this qualification. (I12).

As for the evaluation, there are several contradictions in the teachers' understanding. One of them, for instance, is the value of the daily evaluation, but weaknesses in the filling out of the evaluation format. Also, the teachers show difficulties in carrying out the students' evaluation by integrating the affective, cognitive and psychomotor dimensions.

In this sense, the need for teacher training to carry out the performance evaluation is questioned, considering the criteria defined in the format, or whether it needs to be revised in order to explain what is expected of the student.

Another contradiction is the value assigned to the evaluation aspects that are characteristic of traditional teaching, such as focus on content and with a punitive character, in addition to the fact that the cognitive evaluation is a guiding instrument of the study; principles that oppose meaningful learning.

\section{CONCLUSIONS}

Considering the objectives of this study, it was possible to assess the teaching-learning process through PBL at the UES from the perspective of the teacher of the medical course at the researched institution.

The PBL trajectory in the teaching-learning process of Famema, from the perspective of the teachers, shows us a variety of understandings based on the several experiences lived by the interviewees, in the different professional activities, how long they have used the method, what year they teach and, even their personal perceptions and values. These understandings allowed us to draw a scenario, from the method implementation to the present day.

Regarding teacher training, it is emphasized that the participation in the CE and PE spaces is essential for teachers. However, the strategies used need to be reviewed in relation to the implementation and inclusion of professionals.

As for the evaluation, we observed that the teachers show difficulties in carrying out an evaluation of the students integrating the affective, cognitive and psychomotor dimensions.

Thus, regardless of the time since the curriculum implementation, PE should be a powerful space for teacher training and process management. In this sense, the institution needs to rethink how this training is being carried out, seeking to establish the understanding and adherence to the teaching-learning method.

The reflections provided by the study, although from a local context, allow their extrapolation to other educational institutions, which are seeking educational innovations aimed at meaningful learning and an integrated curriculum.

\section{ACKNOWLEDGEMENTS}

To Fundação de Amparo a Pesquisa do Estado de São Paulo (FAPESP), process number 2015/25784-0.

\section{REFERENCES}

1. Brasil. Lei no 9394/96, de 20 de dezembro de 1996. Estabelece as diretrizes e bases da educação nacional. Diário Oficial da União, Brasília; 1996; Seção1, p. 278-341.

2. Brasil. Diretrizes Curriculares Nacionais do Curso de Medicina. Conselho Nacional de Educação. Câmara de Educação Superior. Resolução no 3, de 20 de junho de 2014.

3. Faculdade de Medicina de Marília. Programa de Incentivo às Mudanças Curriculares dos Cursos de Medicina (Promed): uma nova escola médica para um novo sistema de saúde. Projeto final da Famema. Marília: Faculdade de Medicina de Marília; 2003.

4. Faculdade de Medicina de Marília. Relatório da pesquisa de avaliação do resultado do processo de formação de médicos da Famema. Marília: Faculdade de Medicina de Marília; 2008. 
5. Neville AJ, Norman GR. PBL in the undergraduate MD program at McMaster University: three iterations in three decades. Acad Med. 2007;82(4):370-4.

6. Komatsu RS. Aprendizagem Baseada em Problemas na Faculdade de Medicina de NN: sensibilizando o olhar para o idoso [tese]. Marília: Universidade Estadual Paulista "Júlio de Mesquita Filho"; 2003.

7. Kamp RJA, Dolmans DHJM, Van Berkel HJM, Schmidt HG. The effect of midterm peer feedback on student functioning in problem-based tutorials. Adv Health Sci Educ. 2012;18(2):199-213. doi: 10.1007/ s10459-012-9364-1.

8. Faculdade de Medicina de Marília. Caderno de avaliação do estudante: cursos de Medicina e Enfermagem. Marília: Faculdade de Medicina de Marília; 2011.

9. Marconi MA, Lakatos EM. Fundamentos de metodologia científica. 7a ed. São Paulo: Atlas; 2010.

10. Minayo MCS, organizadora. Pesquisa social: teoria, método e criatividade. Petrópolis: Vozes; 2016.

11. Faculdade de Medicina de Marília. Caderno do Programa de Desenvolvimento Docente. Marília: Faculdade de Medicina de Marília; 2008.

12. Sampieri RH, Collado CF, Lucio PB. Metodologia de pesquisa. 3a ed. São Paulo: McGraw-Hill; 2012.

13. Bardin L. Análise de conteúdo. São Paulo: Edições 70; 2011.

14. Venturelli J, Fiorini VML. Programas educacionais inovadores em escolas médicas: capacitação docente. Rev Bras Educ Med. 2001;25:7-21.

15. Feuerwerker L. Além do discurso de mudança na educação médica: processos e resultados. São Paulo: Hucitec; 2002.

16. Treviso P, Costa BEP. Percepção de profissionais da área da saúde sobre a formação em sua atividade docente. Texto \& Contexto Enferm. 2017;26(1):e5020015 [acesso em 15 de mar 2019]. Disponível em: http://www.index-f.com/textocontexto/2017/26116p.php.

17. Brasil. Portaria no $198 / \mathrm{GM} / \mathrm{MS}$, de 13 de fevereiro de 2004. Institui a Política Nacional de Educação Permanente em Saúde como estratégia do Sistema Único de Saúde para a formação e o desenvolvimento de trabalhadores para o setor e dá outras providências. Diário Oficial da União; 2004.

18. Santos AR, Coutinho ML. Educação permanente em saúde: construções de enfermeiros da estratégia saúde da família. Rev Baiana Saúde Pública. 2014;38:708-24. doi: 10.5327/Z0100-02332014380300016.

19. Tsuji H., Aguilar-Silva RH. Aprender e ensinar na escola vestida de branco: do modelo biomédico ao humanístico. São Paulo: Forte; 2010.

20. Moro C, McLean M. Supporting students' transition to university and problem-based learning. Medical Science Educator. 2017;27:353-61. [acesso em 5 maio 2020] doi: 10.1007/s40670-017-0384-6.

21. Borges MC, Chachá SGF, Quintana SM, Freitas LCC, Rodrigues MLV. Aprendizado baseado em problemas. Medicina (Ribeirão Preto). 2014;47:301-7 [acesso em 5 ago 2020]. Disponível em: http://revista. fmrp.usp.br/2014/vol47n3/8_Aprendizado-baseado-em-problemas.pdf.

22. Moraes MAA, Tonhom SFR, Hafner MLMB, Gomes R, organizadores. Avaliação nos cursos de medicina e enfermagem: perspectivas e desafios. Curitiba: CRV; 2012.

\section{AUTHORS 'CONTRIBUTION}

All authors participated in the design and planning of the research project, data collection, data analysis and interpretation, and the final writing and review.

\section{CONFLICTS OF INTEREST}

We declare that there is no conflict of interest.

\section{ADDRESSS FOR CORRESPONDENCE}

Sílvia Franco da Rocha Tonhom. Avenida Santa Helena, 909, casa

131, Jardim Alvorada, Marília, SP, Brazil. CEP: 17513-322.

E-mail: siltonhom@gmail.com 